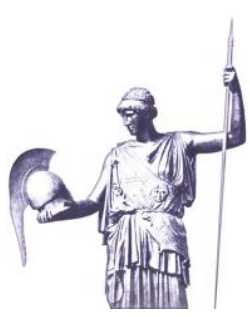

Connections: The Quarterly Journal

ISSN 1812-1098, e-ISSN 1812-2973

Ирина Церцвадзе, Connections QJ 16, № 3 (2017): 83-98

https://doi.org/10.11610/Connections.rus.16.3.05

Рецензированная статья

\title{
Британия и Общая политика безопасности и обороны Европейского Союза
}

\section{Ирина Церцвадзе}

Министерство обороны, Грузия, https://mod.gov.ge/en

Резюме: В этой статье анализируется позиция Британии в отношении Общей политики безопасности и обороны (ОПБО) Европейского Союза в периоде с 1998 по 2016. Рассматривается логика британской позиции по отношению к ОПБО путем поиска ответа на исследовательский вопрос: почему Британия поддержала формирование ОПБО, а затем не всегда последовательно поддерживает ее развитие? Используя подход изучения конкретных примеров, в статье рассматриваются основные моменты развития ОПБО, какими являются: начало функционирования ОПБО (1989-1999); создание оперативных центральных органов (2010-2011); роль Британии в Ливийском кризисе, которая не связана с институциональным развитием, но является очень важной в качестве первой возможности подвергнуть проверке ОПБО после ее старта.

Путем использования двухуровневой теории игр Путнама, в этой статье делается попытка доказать двойную гипотезу, утверждающую, что внутренние дела оказывают влияние на решения Британии в отношении ОПБО, и что развитие событий в Европейском Союзе влияет на британскую позицию по отношению к ОПБО посредством взаимодействия с внутренними факторами.

Ключевые слова: политика безопасности и обороны, ЕС, теория игр, национальный интерес, ОПБО.

\section{Введение}

Любые международные переговоры можно рассматривать как 'игру' на двух уровнях и борьбу за достижение консенсуса - сначала между местными участниками и затем заключение сделки по достигнутому консенсусу 
на международном уровне. Это и есть сущность двухуровневой теории игр Путнама. ${ }^{1}$ На местном уровне люди, определяющие политику, пытаются лоббировать в пользу своей политики перед разными политическими группами и, борясь за власть, они стремятся к созданию разных коалиций, чтобы осуществлять свою политику. На международном уровне переговорщики пытаются минимизировать риск стать жертвой местного давления и минимизируют негативные последствия развития внешних событий. «Каждый [национальный] руководитель, который не успеет удовлетворить требованиям игроков из своей команды, рискует быть изгнанным со своего места», говорит Путнам. ${ }^{2}$

В этой статье анализируется логика британской позиции в отношении Общей политики безопасности и обороны Европейского Союза (ОПБО) до принятия решения о «Брекзите» путем поднятия вопроса: «Почему Британия поддержала формирование ОПБО, а затем не всегда последовательно поддерживает ее развитие?». Ответ можно найти в образе, в котором внутренние британские дела оказали влияние на британские решения в отношении ОПБО, точно так же, как и в том, как развитие событий в Европейском Союзе воздействовало на позицию Британии по отношению к ОПБО.

Похоже, что как показывает Путнам, на решения, принятые британским правительством с 1998 по 2016 в отношении ОПБО, действительно оказывали влияние как внутренняя политика, так и развитие событий в ЕС. Три конкретных примера дают структуру и хронологию исследования. Ими являются:

- Начало функционирования ОПБО: конструктивная роль Объединенного королевства (1998-1999);

- Операционализация ОПБО (2010-2011);

- Роль Британии в Ливийском кризисе (2011).

В зависимости от точки зрения, взятые вместе, эти тематические исследования показывают или разные грани британского способа ведения политики в сфере безопасности и обороны, или особый вид непоследовательности, который в конечном итоге привел к решению о «Брекзите» и его последствий.

\section{Постановка и контекст}

ОПБО является необычным политическим феноменом, который не вписывается в традиционные теории международных отношений, так как она группирует суверенные государства в международную подсистему. Основная путаница происходит из коллективного принятия решений по вопросам

1 Robert D. Putnam, “Diplomacy and Domestic Politics: The Logic of Two-level Games," International Organization 42, no. 3 (Summer 1988): 427-460.

2 Putnam, "Diplomacy and Domestic Politics," 437. 
безопасности и обороны, которые в принципе считаются последним, от чего отказались бы государства-члены ЕС при коллективном принятии решений. Джолион Хауорт, ведущий теоретик в сфере европейской безопасности, описывает ситуацию следующим образом: «Шаги к объединению этого последнего бастиона 'суверенности' - политика безопасности и обороны - со всеми своими ограничениями и оговорками, представляют собой глубочайшую трансформацию образа дальнейших отношений ЕС и его членов с внешним миром». ${ }^{3}$

Это может быть частью проблем Объединенного королевства с ОПБО, но начало 21-го века было отмечено увеличением геополитической нестабильности. Арабская весна, развитие событий в Ливии и Сирии, подъем ИГИС в Сирии и Ираке, российская инвазия в Грузию и Украину, аннексия Крыма и кризис с беженцами - все это предполагало, что нужны новые пути обеспечения безопасности стран-членов Европейского Союза. Как отметила Верховный представитель Европейского Союза по иностранным делам и политике безопасности и вице-президент Европейской комиссии Федерика Могерини: «Во времена вызовов сильный Союз должен думать стратегически, иметь общее видение и действовать сообща. Это тем более верно после британского референдума.» ${ }^{4}$ Очевидно, что кризисы вне границ Союза являются вызовом для ЕС и его ОПБО. Эта политика является феноменом периода после Холодной войны, который проистекает из Маастрихтского договора от 1992 года. ${ }^{5}$ Ее появление связано с конкретным историческим контекстом: интеграцией Западной Европы.

В этом контексте британские лидеры столкнулись с дилеммой, пытаясь добиться баланса между американскими и европейскими интересами, вместо того, чтобы отдать приоритет ЕС. Как это сформулировал один комментатор: «В 1970-х они наклонились слишком далеко в другую сторону, войдя в Европейское сообщество на невыгодных условиях. После 1980-х они снова наклонились в обратную от Европы сторону, передоговорив свой финансо-

3 David R. Smith, The EU Divided: Effects of Dissimilar National Foreign Policies on CSDP (New Haven, Connecticut: Yale University, Yale College, December 2, 2011), https://politicalscience.yale.edu/sites/default/files/files/Smith_Devin.pdf. Jolyon Howorth, "From Security to Defence: The Evolution of the CFSP," in The International Relations of the European Union, ed. Christopher Hill and Michael Smith (Oxford: Oxford University Press, 2005), 182.

4 "High Representative Mogherini presents EU Global Strategy for Foreign and Security Policy," EU Summit, Brussels, 2016, по состоянию на 20 ноября 2016, https://eeas.europa.eu/headquarters/headquarters-homepage/7337/highrepresentative-mogherini-presents-eu-global-strategy-foreign-and-securitypolicy_en.

5 “Maastricht Treaty," February 7, 1992, по состоянию на 15 декабря 2016, http://eurlex.europa.eu/legal-content/EN/TXT/?uri=uriserv\%3Axy0026. 
вый взнос в 1984-85, отказавшись от евро в 1992, присоединившись к американской инвазии в Ирак в 2003, и сейчас полностью расходятся с ЕС. ${ }^{6}$ Исходя из этого политического дискурса, можно было бы предположить, что быть проевропейски настроенным в Британии очень непопулярно: если политики хотели победить во внутреннем споре, им следовало критиковать Брюссель. «Британские министры часто возражали против мер, исходящих из Брюсселя или других столиц, потому что они боялись реакции британских СМИ или британской публики.» ${ }^{7}$

В плане британского подхода к ОПБО Европейского Союза взаимодействие между внутренней и международной политикой очевидно. Именно по этой причине были выбраны в качестве иллюстрации три вышеперечисленные тематические исследования: они лучше всего объясняют положительные, отрицательные и половинчатые роли Британии в ОПБО. Все три примера выделяют разные позиции Британии к институциональному развитию ОПБО и, таким образом, дают нам основу для анализа их подоплеки. Начало функционирования ОПБО является исторически наиболее важным этапом развития этой концепции; без Британии трудно можно представить себе, что она могла бы быть реализована. Создание военно-оперативных центральных органов для ЕС могло быть вторым по значению событием в истории ОПБО, но такого не произошло, потому что Британия отвергла эту идею. Вмешательство ЕС в Ливийский кризис в 2011 году военной силой могло быть первой проверкой для ОПБО, но мнения ЕС были разделены. Для Британии основной вопрос был техническим - участвовать индивидуально, на двусторонней основе с Францией или коллективно в рамках ЕС или НАТО. В плане идеологии Франция, другая большая военная сила в ЕС, была за объединенную и сильную Европу, полагающуюся на свои собственные военные способности. При принятии ливийского решения внутренняя политика воздействовала по-разному на формирование политики безопасности в Лондоне и Париже. В обоих случаях, двухуровневая теория игр Роберта Д. Путнама оказывается полезной для анализа.

Сущность теории состоит в предположении, что международные переговоры характеризуются одновременной активностью на внутреннем и на международном уровне. Национальная переговаривающая группа пытается максимизировать международный «набор выигрышей» по словам Путнама и добивается этого постоянно, учитывая свои собственные внутренние запреты и ограничения. Следовательно, в международном плане соглашения являются результатом сечения выигрышей государств, участвующих в

6 Ian Morris, "A Brief History of Britain's Relationship, Starting in 6000 BCE," Harvard Business Review, Digital Article, June 24, 2016, по состоянию на 20 февраля 2017, https://hbr.org/2016/06/a-brief-history-of-britains-relationship-with-europestarting-in-6000-bce.

7 Charles Grant, "Why Is Britain Eurosceptic," Essay, Center for European Reform, December 19, 2008, по состоянию на 28 февраля 2017, http://www.cer.org.uk/ publications/archive/essay/2008/why-britain-eurosceptic. 
переговорах. Для трех, рассматриваемых здесь примеров, это можно сформулировать следующим образом: для Тони Блэра в 1998, без внутренней поддержки его решения содействовать старту ОПБО, было бы трудно добиться выигрыша. Для Дэвида Кэмерона через десять лет, поскольку он не располагал поддержкой основных политических партий по вопросу создания оперативной штаб-квартиры ЕС, в данном случае нельзя было добиться выигрыша для ЕC.

\section{Применение двухуровневой теории игр к исследуемым примерам}

Согласно Роберту Д. Путнаму, внутренняя политика является критически важной в любой теории международных переговоров. Сила и предпочтения главных политических акторов на внутреннем уровне следует брать в расчет. Если на международном уровне можно добиться большого выигрыша, главному переговорщику нужно помнить, что все субъекты на внутреннем уровне будут принимать участие в процессе ратификации. ${ }^{8} \mathrm{Ha}$ уровне ЕС этот теоретический подход показывает, что когда придет время принимать решения, каждый из членов ЕС больше думает о потенциальных внутренних последствиях и меньше об общем благе ЕС в целом.

\section{Запуск ОПБО / Конструктивная роль Британии (1998-99)}

После окончания Холодной войны у Соединенных Штатов были другие приоритеты во внешней политике, а не гарантирование безопасности Западной Европы. Начала формироваться новая парадигма безопасности. После падения Берлинской стены политики в Вашингтоне переключили свое внимание на Азию, на Залив и на Ближний Восток, акцентируя на том, что Европа больше не является проблемой. Подход США был простым: европейская безопасность должна была обеспечиваться самими европейцами. Войны в Югославии в 1990-х скоро показали неспособность Европейского Союза гарантировать безопасность в континентальной Европе. Развитие событий сделало очевидным, что ЕС нуждался в постоянной системе безопасности и обороны, на которую он мог бы рассчитывать.

После конца Холодной войны идея Общей Политики Безопасности и Обороны была объявлена после введения Общей Внешней Политики и Политики Безопасности в качестве второго столба ЕС в соответствии с Маастрихтским договором. Однако, ее реализация началась не сразу. На практике, она стала возможной только после саммита в Сен-Мало в 1998.

Хорошо известно, что лейбористское правительство, которое пришло к власти в 1997, было определенно намного проевропейское, чем любой из его предшественников. «Тони Блэр пришел сильным и с программой мо-

8 Putnam, "Diplomacy and Domestic Politics." 
дернизации, которая как будто ставила Европу в центр британских интересов и наоборот. ${ }^{9}$ В широких кругах считается, что самым важным аспектом европейского наследства Блэра является саммит в Сен-Мало, где вместе с французским президентом, Жаком Шираком, он попытался запустить для Европы реальную внешнюю политику и политику безопасности. Саммит в Сен-Мало в сентябре 1998 закончился принятием декларации, подчеркивающей значение безопасности и то, что механизм реализации и способность развертывать силы имели существенное значение для внешней политики EC.

Эта часть тематического исследования очень хорошо иллюстрирует связанное с Путнамом представление, что внутренние дела оказывают влияние на британские решения в отношении Общей Политики Безопасности и Обороны. Однако, не следует пренебрегать и международным уровнем. В то время было три важных момента. Первым была доминирующая роль США в европейской обороне; второй - последствия войн в Югославии; и третий - готовность самого ЕС укреплять безопасность и оборонные способности. Вместе эти аспекты порождали взаимодействие между внутренними и международными факторами и работали на положительное решение: на практике в выигрыше оставались и Британия, и ЕС. Декларацией саммита в Сен-Мало Британия вместе с Францией стремились к трансформации ЕС в позитивного актора на поле безопасности в Европе и для Европы путем вооружения себя теми военными способностями, которых настолько очевидно не хватало в недавних югославских конфликтах.

Формулировки декларации, которую Британия и Франция подписали, были четкими и требовательными: «... Союз должен располагать способностью действовать автономно, обеспеченной надежными вооруженными силами, механизмами принятия решения использовать их и готовностью делать это для того, чтобы реагировать в ответ на международные кризисы.» ${ }^{10}$ Для некоторых теоретиков эта декларация на отражала истинные намерения: «Даже если и Британия была настолько готова поддержать проект европейской обороны после инициативы Сен-Мало вместе с Францией в 1998, идея Британии была в большей степени руководить, чем просто участвовать. Если на континенте собирались объединяться и, таким образом, компенсировать индивидуальные слабости, работая вместе, то это было прекрасно, но для самого Объединенного Королевства, конечно, не было необходимости полагаться на такие перемены.» ${ }^{11}$ Это не удивительно, учитывая

9 Simon Berlaymont, "Tony Blair and Europe," Open Democracy, free thinking for the world, May 30, 2007, по состоянию на 31 января 2017, www.opendemocracy.net/ tony_blair_and_europe.jsp.

10 Joint Declaration issued at the British-French Summit, Saint-Malo, Foreign and Commonwealth Office of the United Kingdom, August 12, 2008, http://www.fco.gov.uk/ en/newsroom/latest-news/?view=News\&id=2244063.

11 Clara Marina O'Donnell, "Britain and France should not give up on EU defence cooperation," Policy Brief, Center for European Reform, October, 2011, по состоянию 
историческое наследство Британии как империи, которая не верит в надежные военные партнерства с европейскими странами. Кроме того, британский атлантизм и 'специальные' отношения с США дают основание некоторым теоретикам утверждать, что «США последовательно оказывали давление на Объединенное Королевство стать полноценным и активным участником всех сфер политики ЕС, в том числе обороны и безопасности. Это было одной из основных причин того, что Тони Блэр поехал в Сен-Мало. Если Объединенное Королевство оказалось бы вне ЕС, что оно могло предложить США в плане безопасности и обороны? „12 Поэтому можно сказать, что позиция британских политиков - и Тони Блэра, в частности - в большой степени была сформирована влиянием развития событий в ЕС, в особенности желанием самого ЕС укрепить безопасность и оборону, и на более широком международном уровне, когда США оказались очень заинтересованными в сильном ЕС, ответственным за безопасность его границ.

Подводя итоги первого случая, надо отметить, что запуск ОПБО не был результатом только развития событий в Британии или только в ЕС. Можно даже пойти дальше и сказать, что основным фактором была ограниченная роль Соединенных Штатов в европейской безопасности. Несмотря на факт, что Тони Блэр был лидером лейбористской партии, он был большим энтузиастом в отношение ЕС, чем кто-либо в британской лейбористской партии. Благодаря изменившейся политической среде и взаимодействию внутренних и международных факторов, его политика на посту премьер-министра Британии отличалась от политики предшествовавших правительств. Никто не возражал против того, чтобы он взял на себя ведущую роль в ОПБО. Он очень хорошо понимал, чего США ожидали от Британии - взять в свои руки инициативу в Европе, чтобы гарантировать сильное партнерство. Придя к заключению, что для Британии было бы неприемлемо войти в Еврозону и в Шенгенское соглашение, он сконцентрировался на сферах безопасности и обороны. Это так же соответствовало исторической британской традиции располагать могучими вооруженными силами. Однако, рассматривая роль Британии в ОПБО через почти двадцать лет, можно предположить, что это решение было скорее тактическим, чем стратегическим, поскольку очень скоро после принятия этого исторического решения Британия изолировала себя от основного институционального развития ОПБО. В следующих изучаемых примерах будет рассмотрено дальнейшее развитие ОПБО и роль Британии в нем.

на 15 марта 2017, www.cer.org.uk/sites/default/files/publications/attachments/pdf/ 2011/pb_csdp_24oct11-3907.pdf.

12 Jolyon Howorth, "The CSDP without the UK: bad for Europe but even worse for Britain," in The Common Security and Defence Policy: National Perspectives, ed. Daniel Fiott (Brussels: The Royal Institute for International Relations, May 2015), 19, по состоянию на 15 марта 2017, http://aei.pitt.edu/64766/1/ep79.pdf. 
Первоначальное развитие ОПБО: Объединенное Королевство блокирует Оперативную штаб-квартиру (2010-2011)

Лиссабонский договор, который был подписан в 2007 году и вступил в силу в 2009, касается проведения более сильной и более сфокусированной централизованной внешней политики при помощи существенно усовершенствованных инструментов, находящихся в ее расположении. Договор отражает переход от Европейской Политики Безопасности и Обороны (ЕПБО) к ОПБО. «Согласно Лиссабонскому договору, роль Верховного представителя Союза по иностранным делам и политики безопасности была усилена для укрепления голоса EC на мировой арене. Он будет председателем Совета по иностранным делам и Вице-президентом Комиссии. Работу Верховного представителя будет поддерживать новая Европейская служба внешних действий.» ${ }^{13}$

Лиссабонский договор ввел важные положения, связанные с ОПБО, в том числе параграф о взаимопомощи и солидарности и расширение Петерсбергских задач. ${ }^{14}$ Создание Оперативной штаб-квартиры (ОШК) стало одной из главных проблем в отношениях между ЕС и Британией после того, как к власти пришла Консервативная партия Дэвида Кэмерона. Для Кэтрин Эштон, Верховного представителя ЕС по иностранным делам и политике безопасности, создание ОШК было тесно связано с выполнением Лиссабонского договора. Но их будущее в большой степени определило взаимодействие внутренних и международных факторов в ходе текущего дискурса создания ОШК.

Как говорит Алистер Джонс, несмотря на факт, что именно Консервативное правительство привело Британию в Европейское Экономическое Сообщество в 1973, Консервативная партия по традиции всегда была настроена евроскептически. ${ }^{15}$ Маргарет Тэтчер видела роль Британии как решающую для Союза, и для нее быть 'внутри' означало более эффективно защищать

13 Herbert Smith Freehills LLP, "The Lisbon Treaty - brief overview of the key changes," European Union, November 4, 2009, по состоянию на 13 мая 2017, www.lexology.com/ library/detail.aspx?g=48a4327a-c5e8-41a7-8000-c93e90abe763.

14 Петерсбергские задачи были поставлены Петерсбергской декларацией, принятой Советом министров Западно-европейского союза (ЗЕС) в июне 1992. В данном случае, страны-члены ЗЕС заявили о своей готовности предоставлять ЗЕС, но также НАTO и ЕС военные формирования широкого спектра своих конвенциональных вооруженных сил. К настоящему времени список Петерсбергских задач включает: гуманитарные задачи и задачи по спасению; задачи по предотвращению конфликтов и сохранению мира; задачи боевых сил при антикризисном менеджменте, в том числе миротворчество; совместные операции по разоружению; задачи по военному консультированию и оказанию помощи; задачи по пост-конфликтной стабилизации. http://eur-lex.europa.eu/summary/glossary/ petersberg_tasks.html.

15 Alistair Jones, Britain and the European Union (Edinburgh University Press, 2007). 
британские интересы. ${ }^{16}$ Но руководители после Тэтчер не всегда рассматривали ее таким образом. Дэвид Кэмерон, к примеру, иногда воспринимается как наиболее евроскептический лидер своей партии. Это легко можно понять, рассматривая осторожную политику, которую он проводил в отношение ОПБО.

Дэвид Кэмерон был очень осторожен в политике в отношение ЕС с первого дня своего прихода к власти. На внутреннем уровне он знал, что большинство членов его партии были евроскептиками и заботился о том, чтобы избежать риска потери внутренней поддержки. Действительно, действия Кэмерона по избеганию активной роли на уровне ЕС прекрасно иллюстрируют первый фактор теории Путнама, состоящий в том, что размер выигрыша зависит от внутренних политических институций. Поэтому он старался не допустить утраты поддержки внутренних институций. Независимо от этого, ему так же надо было брать в расчет взгляды его про-ЕС коалиционных партнеров и активную дискуссию в СМИ о выходе Британии из ЕС в качестве существенных факторов при принятии каких-либо решений, связанных с ОПБО.

Кэтрин Эштон, британский лейбористский политик, была первым Верховным представителем ЕС по иностранным делам и политике безопасности после создания этого поста в соответствии с Лиссабонским договором. Она рассматривала создание ОШК как часть выполнения Лиссабонского договора. В этом плане ее решительно поддерживали Германия и Франция. Но настолько же решительно ей противодействовало британское правительство. В итоге, штаб-квартиры не были организованы. Как комментировала Эштон, «Речь шла о выполнения того, в чем сущность Лиссабонского договора. ... Позиция нынешнего британского правительства такая же, как и у предыдущего. Это не было ударом, это не было неожиданностью. Важно выкладывать идеи на стол, даже если государства-члены решают их отвергнуть. ${ }^{17}$

Консервативный министр иностранных дел, Уильям Хейг, был обеспокоен тем, что инициатива леди Эштон может дать ЕС новые способности в сфере безопасности, что потребовало бы дополнительного финансирования в период больших финансовых сокращений и могло так же подорвать роль НАТО. После ссоры, обозначившей наиболее серьезное расхождение Британии с леди Эштон, он предупредил, что любое упоминание военных штабов ЕС вызовет незамедлительное британское вето. ${ }^{18}$ Таким образом,

16 Jones, Britain and the European Union, 27.

17 Bruno Waterfield, "Britain blocks EU plans for 'operational military headquarters'," The Telegraph, July 18, 2011, по состоянию на 20 марта 2017, www.telegraph.co.uk/ news/worldnews/europe/eu/8645749/Britain-blocks-EU-plans-for-operationalmilitary-headquarters.html.

18 Waterfield, "Britain," 28. 
хотя многие страны-члены ЕС, в том числе и Франция, решительно поддерживали инициативу создания военных штабов ЕС, из-за британского вето она никогда не была реализована.

Анализ этого примера демонстрирует постоянное взаимодействие между внутренними и международными факторами, которое в данном случае не принесло плодов желаемого выигрыша для ЕС. Как и в первом примере, мы можем утверждать, что когда Британия принимала решение о создании оперативного штаба ЕС, на Кэмерона оказывали влияние множество факторов, включая развитие событий в ЕС. ЕС был в процессе восстановления от финансового и экономического кризиса 2008 года, и страны не решались тратить деньги на многосторонние обязательства; страны-члены возражали против шагов, связанными с увеличением расходов на оборону и безопасность.

Как и в Сен-Мало, налицо было идеологическое разделение: Объединенное Королевство не усматривало концептуальной необходимости в военных штабах ЕС. Вместо этого Британия предлагала применять кооперативный подход, а не создавать новую институцию. Идея Хейга была улучшить связи между существующими национальными штабами. Саймон Смит говорит: «Ответ Объединенного Королевства всегда следующий: нам такой не нужен, и в Европе уже имеется множество штаб-квартир. Они также ставят вопрос, какой вид военной миссии является настолько большой, чтобы с ней не справился национальный штаб? И если таковая имеется, то скорее всего в нее будет вовлечено НАТО. Но это упускает из виду необходимость ОПБО быть в состоянии провести адекватное планирование перед большими кризисами, в особенности комбинированное гражданско-военное планирование. ${ }^{19}$

С британской точки зрения, причины для несогласия с ОШК были финансовыми и чтобы не дублировать роль НАТО в Европе. Предотвращение принятия решения об оперативной штаб-квартире для Британии можно рассматривать как существенный выигрыш, достигнутый на международной арене. Но выгоду получило не только Объединенное Королевство. Как указывает Даниель Фиотт,

Конечно, представители Объединенного Королевства были скептически настроены из-за отсутствия необходимой политической воли и способности Европы финансировать, обеспечить персоналом и использовать такую большую ОШК. Было очень трудно найти стран-членов, готовых инвестировать в такие способности вообще, независимо от ОПБО. Все

19 Simon J. Smith, "European Defence, CSDP and the UK: two cases of catch-22," in The Common Security and Defense Policy: National Perspectives, ed. Daniel Fiott (Brussles: The Royal Institute for the International Relations, 2015), по состоянию на 17 февраля 2017, http://aei.pitt.edu/64766/1/ep79.pdf. 
страны спрашивали, как дорого это нам будет стоить, если их надо будет использовать? ${ }^{20}$

К тому времени, в 2011 году ЕС уже осуществляло несколько заграничных военных миссий и операций, например, миссию по борьбе с пиратами у побережья Сомали и миротворческую миссию на Балканах, ни одна из которых не была скомпрометирована из-за отсутствия многонационального штаба. Британский аргумент об эффективности текущих военных операций, руководимых национальными штабами, основывался на миссии ЕУНАВФОР Аталанта, чей штаб находился в Нортвуде, Объединенное Королевство.

\section{Роль Объединенного Королевства в Ливийском кризисе (2011)}

Весной 2011 года президент Ливии, Муаммар Каддафи, использовал силу для подавления народного восстания против его режима. Ливийский кризис был «одним из кусочков более широкого паззла Арабской весны», которая распространялась с побочными эффектами на Ближнем Востоке и в Северной Африке. ${ }^{21}$ В отличие от предыдущих двух изучаемых примеров, роль Британии в Ливийском кризисе нельзя определить как решение поддержать или заблокировать институциональное развитие ОПБО. Кризис в Ливии подвергнул проверке ОПБО и Британия, наряду с другими военными силами в ЕС, определенно сыграла некую роль в этом контексте.

Франция, в частности, оказалась в положении убеждающего европейских партнеров прибегнуть к военным действиям. Из-за бездействия и нежелания США, Британия и Франция сперва направили свои усилия на принятие резолюции 1973 Совета Безопасности ООН. Похоже, Лондон и Париж считали, что обеспечение мандата ООН более важно, чем взятие ЕС на себя управление ливийскими операциями. Это можно объяснить также фактом, что эти две страны не хотели передавать оперативное управление органу EC, предпочитая полагаться на линии командования своих военно-воздушных сил.

Для Британии выигрышем в Ливийском кризисе было эффективное военное участие. Вопрос был техническим: будет ли операция под эгидой ЕС или под эгидой НАТО. Кэмерон располагал внутренней поддержкой: лейбористский лидер, Эд Милибенд, выразил полную поддержку военным действиям, и Палата общин одобрила военные действия 557 голосами против 13. Общественное мнение против Каддафи в Британии уже было очень сильным. До начала операции в Ливии надо было эвакуировать британских нефтяников, чтобы они не оказались в сложной ситуации. Кроме того, силы безопасности Каддафи задержали и подвергли побоям членов рабочей

20 Daniel Fiott, ed., The Common Security and Defense Policy: National Perspectives, EGMONT Paper 79 (Brussels: The Royal Institute for the International Relations, 2015), по состоянию на 15 марта 2017, http://aei.pitt.edu/64766/1/ep79.pdf.

21 Maxime H.A. Larivé, Debating European Security and Defense Policy: Understanding the Complexity (Aldershot, Burlington: Ashgate Publishing Company, 2014), 209. 
группы БиБиСи, и шестеро членов одной из команд элитных специальных сил Объединенного Королевства предположительно были взяты в плен и задержаны. 22

На Кэмерона оказывали влияние в основном международные факторы, поскольку внутреннее мнение в Объединенном Королевстве в отношении интервенции в Ливию в соответствие с ОПБО не было настолько проблематическим, насколько могло бы быть. Позиции стран-член ЕС были фрагментированными. Действительно, особые отношения с ливийским государством в связи с нефтяными сделками приводили к тому, что некоторые государства-члены не хотели предпринимать действия. Не было единой позиции по разрешению кризиса с использованием военных способностей ЕС. Это противоречие между внутренним и международным уровнями оказало существенное влияние на Кэмерона, чтобы он не настаивал на применении ОПБО. Если на уровне ЕС среди стран-членов имелся консенсус, означающий большой выигрыш, это оказало бы положительное воздействие на окончательное решение и на результат в отношении ОПБО. Но среди странчленов ЕС по разным внутренним причинам консенсус по Ливии отсутствовал. К разочарованию пуристов ОПБО, 20 лет после балканских кризисов, когда была запущена ОПБО, Ливийский кризис выглядел как тот сценарий, для которого была и создана ОПБО. В результате, отсутствие централизованного органа командования и управления самого ЕС стало причиной ограниченной возможности действовать быстро. ОПБО не могла быть ведущим инструментом, в институциональном плане она не была в постоянной готовности.

Ливийская интервенция началась 19 марта 2011 года, после того как 17 марта Совет безопасности ООН одобрил создание «запрещенной для полетов зоны». Операция проводилась под зонтом поддержки НАТО, а руководство осуществлялось совместно Британией и Францией. Это показало, что даже через 20 лет после Балканских войн Западная Европа не была способна самостоятельно обеспечить запрещенную для полетов зону без содействия НАТО. ${ }^{23}$ Что касается реальной операции, вместе с США Объединенное Королевство запустило 12 ракет Томагавк с подлодки у побережья Ливии, а также предоставило одну базу Королевских военно-воздушных сил. ${ }^{24}$ После атаки в британской прессе появились статьи, утверждающие, что к примеру: «До 20 процентов от Томагавков Объединенного Королевства были использованы за прошедшие четыре дня в Ливии, вызывая

22 "Timeline: UK's road to action in Libya," BBC News, April 15, 2011, accessed April 2, 2017, http://www.bbc.com/news/uk-politics-12821505.

23 Полезно вспомнить, что Германия воздержалась при голосовании в Совете безопасности ООН по вопросу введения зоны, запрещенной для полетов.

24 Thomas Harding, "Libya: Navy running short of Tomahawk missiles," The Telegraph, March 23, 2011, по состоянию на 5 апреля 2016, http://www.telegraph.co.uk/news/ worldnews/africaandindianocean/libya/8400079/Libya-Navy-running-short-of-

Tomahawk-missiles.html. 
страхи, что Британии сжигает свой арсенал.» ${ }^{25}$ В двух словах, очень небольшое участие на границах Европы выставило на показ хрупкость оборонных способностей Британии, момент, который усилил ее скептицизм в отношении многонационального командования и управления операциями. Реакция ЕС на Ливийский кризис была демонстрацией факта, что ЕС не может использовать свои военные и оборонные способности в многонациональной рамке без консенсуса в рамках ЕС. Это было обобщено Международным институтом исследований по вопросам обороны следующим образом: «Они показали напрасность претензий, что Лиссабонский договор от 2009 года может сделать ЕС более способным предпринимать действия, чем он был во время кризисов на Балканах.»26

Рассматривая элементы набора выигрышей для Объединенного Королевства с точки зрения двухуровневой теории игр Путнама, можно сказать, что выигрыш в Ливийском кризисе зависел как от внутренних, так и от международных факторов. Кэмерону не пришлось воевать слишком сильно на внутреннем уровне. Тем не менее, внутренние факторы участвовали во взаимодействии внутри ЕС- который не имел единой позиции по интервенции с использованием ОПБО. Если бы ЕС имел решительную позицию, результат от применения ОПБО, возможно, был бы другим. Мы можем сделать вывод, что в ходе переговоров результат зависел от размера выигрыша, больший выигрыш означал быть успешным. Таким образом, если ЕС имел бы больший выигрыш, т.е. имелся бы консенсус между странами-членами по интервенции в Ливию, конечный выигрыш, сама интервенция могла быть другой, поскольку общее решение ЕС оказало бы влияние на позицию самой Британии.

Было бы разумным предположить, что даже в случаях, когда у Британии не было четко положительной или отрицательной позиции в отношении ОПБО, взаимодействие между внутренними и международными факторами все равно имело бы место. В случае с Ливией, вмешательство с использованием ОПБО не было выигрышем для Британии - выигрышем была сама интервенция, - но выигрыш был в другом для ОПБО/ЕС, который имел свои проблемы с согласованностью политики на тот момент.

\section{Заключение}

Три изучаемые примера помогают ответить на исследовательский вопрос: «Почему Британия поддержала запуск ОПБО, но не поддерживает последовательно ее развитие?». Взаимодействие между внутренним и международным уровнями очевидно во всех трех примерах, но уровень противоречий для трех случаев является разным. Мы можем сказать, что в Британии

25 Harding, "Libya," 32.

26 "War in Libya: Europe's confused response," The International Institute for Security Studies, Volume 17, Comment 18, April 2011, по состоянию на 28 февраля 2017, http://deps.panteion.gr/images/Libya-Europe-confused-response.pdf. 
никогда не было сильного про-европейского движения в отличие от других стран-членов ЕС. Членство в ЕС было важным для Британии и без того, чтобы она играла в нем полную роль. В британском обзоре стратегической обороны и безопасности за 2015 год нет ни одного упоминания о роле Британии в ОПБО. ${ }^{27}$ Некоторые теоретики интерпретируют это, будто Британия пренебрегает Общей политикой безопасности и обороны, рассматривая отдельно от ЕС свои вызовы и возможности во время периода, когда она являлась частью ОПБО. Определенно, британская позиция в отношении ОПБО всегда была результатом взаимодействия между внутренними и международными факторами. С уверенностью можно сказать, что концепция Путнама о выигрыше, в целом, помогает объяснению внутреннего и в плане иностранных дел подхода Британии к ОПБО.

Первый изучаемый случай, запуск ОПБО, является примером того, как Британия толкала в сторону ОПБО. Роль Британии в ОПБО широко обсуждалась после европейской попытки добиться автономии в сферах безопасности и обороны. Декларация саммита в Сен-Мало была подписана в декабре 1998 британским премьером Тони Блэром и французским президентом Жаком Шираком, которые встретились, чтобы содействовать созданию Европейской политики безопасности и обороны, включая создание европейских вооруженных сил, способных вести автономные действия. Декларация саммита Сен-Мало была ответом на вооруженный конфликт в Косово в конце 1990-х, в котором действия международного сообщества, и в частности Европейского Союза и его членов, были восприняты как провал интервенции, направленной на прекращение конфликта. Факт, что британское правительство настаивало на Политике безопасности и обороны ЕС, был воспринят широким кругом теоретиков как желание Британии возглавить ОПБО. Этот первый случай является демонстрацией первого фактора выигрышного варианта, Британия решительно стояла за укрепление оборонных способностей ЕС, и в этом плане имелся консенсус на внутреннем уровне. Но решение, принятое в Сен-Мало, оказало для Британии как внутреннее развитие событий, так и развитие событий в ЕС, что отражает параллельные уровни теории игр Путнама.

Второй изучаемый случай, период 2010-2011, показал, что блокирование Британией оперативного развития и создания ОШК, имело другой результат, но теория остается применимой для Объединенного Королевства. Создание Оперативного штаба стало одной из главных проблем отношений ЕС-Британия после прихода к власти Консервативной партии Дэвида Кэме-

27 "National Security Strategy and Strategic Defence and Security Review 2015," Policy Paper (UK Government, November 23, 2015), по состоянию на 10 апреля 2017, https://www.gov.uk/government/publications/national-security-strategy-andstrategic-defence-and-security-review-2015. 
рона. Кэтрин Эштон считала, что создание ОШК «означало выполнить основное требование Лиссабонского договора». ${ }^{28}$ Этот случай проанализирован через призму второго фактора выигрышного набора, при котором успех зависит от стратегий переговорщиков на международном уровне; выигрышной политикой для традиционно евроскептического правительства Дэвида Кэмерона было заблокировать создание Оперативного штаба ЕС - и снова на это решение оказали влияние как внутренняя политика в Британии, так и развитие событий в ЕС.

Третий рассматриваемый случай, который сконцентрирован на британской роли в Ливийском кризисе, не касается в такой степени роли ОПБО в институциональном развитии, как возможности проверить ОПБО в реальном сценарии, и как Британия и другие страны косвенным образом ее провалили. На внутреннем уровне Кэмерон не встретил сопротивления военному участию в разрешении кризиса, но на уровне ЕС и на более широком международном уровне имелись противоречивые факторы, которые и определили британскую позицию. Во-первых, у членов ЕС не было единомыслия по поводу Ливии; ОПБО всегда оказывалась трудным для использования инструментом. Во-вторых, Объединенное Королевство оказало предпочтение двустороннему участию с Францией. В-третьих, имелся естественный уклон в сторону НАТО, который, что касается Франции, был причиной того, что операция была проведена под зонтом НАТО. В отношение Франции можно утверждать, что у нее было принципиальное предпочтение к сильной и объединенной Европе, но в случае Ливийского кризиса не было необходимых соглашений в рамках ЕС. Для Британии вопрос лидерства в Ливийской операции был чисто техническим. Имелось решение принять участие, но не решение принимать участие через ОПБО. Британия никогда не верила в военные способности ЕС. Предыдущие примеры показывают, что даже когда она поддерживала идею ОПБО, это было результатом развития событий в ЕС и США и никогда не предполагало полного безусловного участия.

Эта статья и примененная теоретическая рамка дают пищу для рассуждений о будущем как Британии, так и ОПБО. В целом, мы можем рассматривать ОПБО как будущее глобальной безопасности ЕС. Ясно, что Британия не может избежать военного сотрудничества со странами-членами ЕС. Возможно, после «Брекзита» условия сделают такое сотрудничество еще более тесным. Наше исследование показывает, что Британия никогда не чувствовала себя комфортно, разделяя военную независимость на многостороннем уровне, кроме как в рамках НАТО. Но НАТО - это отдельный случай, все согласны, что ведущую роль в организации имеют США, и поддерживая исторически варьирующие, но как правило, тесные связи с США, Британия воспринимается как европейский союзник Вашингтона в НАТО.

28 Waterfield, "Britain," 28. 
После решения о «Брекзите» министр обороны Германии обвинил Британию в 'парализовании' ОПБО. ${ }^{29}$ Однако, это может оказаться поверхностным суждением. Вещи, по традиции, лучше работают на двустороннем уровне. Поэтому, в следующие пять лет мы можем стать свидетелями разных форм сотрудничества, основанных на концепции 'плюс' - это может быть Британия плюс США; Британия плюс ЕС; Британия плюс страны-члены; и даже Британия плюс неевропейские страны. Что касается ОПБО, многие теоретики утверждают, что «Брекзит» дает импульс ЕС вдохнуть новую жизнь в его политику безопасности и обороны. Дополнительным фактором являются Соединенные Штаты и президент Дональд Трамп, который, судя по его заявлениям, не склонен способствовать европейской безопасности. Возможно, это больше, чем любой другой фактор, станет катализатором расцвета ОПБО - наконец.

\section{6 авторе}

Ирина Церцвадзе является начальником Отдела европейской интеграции и отношений с международными организациями Министерства обороны Грузии с мая 2015 года. До этого она работала в парламенте Грузии в комитете по европейской интеграции, где отвечала за сотрудничество с международными организациями, местными НПО и информационными порталами СМИ. Ее опыт включает пять лет работы международным журналистом в Москве, Россия, корреспондентом Грузинского общественного вещателя (2007-2008) и международным вещателем в грузинской службе Голоса Америки, Вашингтон, США (2009-2010). У нее степень бакалавра по международной журналистике, полученная в Тбилисском государственном университете, диплом специалиста ТВ журналистики, полученный в Московском государственном университете, и степень магистра по международной и европейской безопасности, полученная в Университете Женевы. Она является выпускником Европейского центра исследований по вопросам безопасности и была членом преподавательского состава ЦИДМ в 2014 году. Она также участвовала в программе СПгл Грузинского фонда стратегических и международных исследований в 2012. В настоящее время Ирина является аспирантом государственного университета Ильи, Тбилиси. Ирина свободно говорит на грузинском, английском и русском языках.

29 Daniel Keohane, “Can France and Germany lead European Defence?" Europe's World, по состоянию на 12 апреля 2016, www.friendsofeurope.org/publication/canfrance-and-germany-lead-european-defence. 